\title{
Chetwynd, Josh and Belton, Brian A. (2007). \\ British Baseball and the West Ham Club: History of a 1930s \\ Professional Team in East London, McFarland. ${ }^{\dagger}$
}

\author{
石 原 豊 一*
}

\section{Toyokazu ISHIHARA*}

そろそろ巷では, ロンドン五輪のことが話題 にのぼっている。本稿が公刊されている頃に は, 日本のメダルの行方も決まり, 次回大会に 向けての競技の変更も検討されているかもしれ ない. 前北京大会後に除外された野球について も，復活に向けた具体策が取り沙汰されている ことだろう。ここで英国に展開されたプロ野球 リーグの歴史を叙述した 5 年前発刊の本書を紹 介する理由は, そのタイトルからご理解いただ けると思う. 野球競技が除外されてしまった今 回の五輪が開かれた英国には, 知られざる野球 の歴史があったのだ。それを発掘したのが本書 である.

ところで, 野球の初代世界チャンピオンはど この国かご存じだろうか. ワールド・ベースボー ル・クラシック（WBC）を念頭において日本 と答える人もいるかもしれない. しかし，あま り知られてはいないが, アマチュアの統括組織 である国際野球連盟（IBF）が主催するワール ドカップは，実は長い歴史を持っている.

サッカーが, アマチュアリズムのまだ濃い「文 化へゲモニー」 ${ }^{1)}$ の時代に英国から世界中に広 がったのに対し, 米国生まれの野球は, マグガ イヤーが、スポーツにおける英米のへゲモニー の交替期であると指摘する戦間期から1950年代 に世界的な普及を始め ${ }^{2)}$, 現在グローバルな拡
大を遂げつつある。

しかし，世界規模でのトップリーグである MLBが，域内でのリーグ戦興行に重きを置き， 国際大会開催に消極的であったせいもあって (このことが五輪からの野球競技削除の主要因 であるのだが)，このリーグの世界戦略の一環 として始まったWBC以前においては, アマチュ アによるワールドカップ（W杯）がこの競技に おける「世界一」を決める大会であった。

$\mathrm{W}$ 杯は，第二次世界大戦のため実施されず幻 に終わった東京五輪に備えた米国代表チーム が，英国に遠征し，リバプールなどで行った 5 試合の対抗戦にその源流を求めることがで きる.このシリーズに英国代表は 4 勝 1 敗で 勝ち越したのだが，東京五輪が中止されたた め, IBFは, 後付けでこのシリーズを「第 1 回 ワールドカップ」に認定し，英国が野球におけ る初代「ワールドチャンピオン」となった。五 輪出場を想定した米国代表チームは，のちのメ ジャーリーガー 2 人を擁するなど, 当時として はアマチュア最高レベルのチームであったと 言ってよく，それを下した英国代表チームは相 当に実力があったと言える。但し，これにはか らくりがあって, 実際には, この英国代表メン バーのほとんどは二重国籍のカナダ人で占めら れていた。この点, 現在のスポーツの商業化の

\footnotetext{
†原稿受付 2012年 2 月27日 原稿受諾 2012年 4 月17日

*立命館大学大学院 =603-8577 京都府京都市北区等持院北町56-1

*Graduate School of Ritsumeikan University, 56-1, Tojiin-kitamachi, Kita-ku, Kyoto, Kyoto, Japan (603-8577)
} 
下, 英国籍を取得した外国生まれの選手が,「英 国代表」として五輪に出場している現状を彷彿 とさせる.

米国の「ナショナル・パスタイム」である野 球は, その誕生直後からプロ化を指向した点で アメリカンスポーツの典型と言ってよい競技 である，このスポーツが, 英国でプロリーグと して展開されていたことを知っている人は多く はないだろう．英米のへゲモニーが後退しつつ あったこの時代に，いかに野球がプロスポーツ として英国で展開されていたのかを, 本書は描 いている.

本書の冒頭に述べられている, 野球草創期と 言ってよい1890年という早い時期に野球という アメリカンスポーツがプロスポーツとして英国 に伝わった事実には, 多くの読者が驚くに違い ない. 本場米国において野球をビジネスに仕立 て上げた,アルバート・スポルディングも加わっ たこの試みは, 時期尚早であったようで, この リーグはたった 1 年で消滅してしまう.その後, 20世紀の初めまでは, 野球は「冬の時代」を迎 え, 米国からメジャーリーグの遠征が行われる ことがあっても, 物珍しさ以上の興味を英国人 から引き出すことはできなかった。

本書では, 1930年代に首都ロンドン周辺に おいて展開されたプロリーグ,「ロンドン・メ ジャーリーグ」の「ウェストハム・ハンマーズ」 の盛衰の過程を追うことにより, 英国における, 米国生まれの野球というスポーツの興亡の歴史 が概観されている.

このリーグの成功を端緒に, 英国は 3 リーグ が展開されるプロ野球隆盛の時代を迎える。し かし, 当時流行のグレイハウンドレース場を転 用した, 中堅までの距離が極端に短い球場など の決して良いとは言えないプレー環境や, 迫り くる第二次世界大戦などから, これも長くは続 かなかった。

しかし，このような外的要因だけが，英国プ 口野球が短命に終わった原因ではないと評者は 考える.スポーツの発展史におけるこの時代は, いまた，強者の文化がその影響の及ぶ地域の人
びとに憧憬をもって迎え入れられた「文化へゲ モニー」の時代であり，英米のへゲモニーの交 替期であったこの時期，欧州においては，英国 スポーツが依然としてへゲモニーを握っていた ことを英国プロ野球の事例は示しているのであ る.

それに対し, 現在のスポーツの拡大は, 資本 と結びついた収益の装置としてのそれであると 言える ${ }^{3)}$. 野球について言えば, このスポーツ は北米トップリーグ・MLBの選手獲得網，マー ケットの拡大という形で現在世界規模に拡大し ている.「文化へゲモニー」の時代には根付か なかった欧州（イタリア）や豪州にプロリーグ が近年（2010年）発足した事実は，野球が現地 で根付いているか否かよりも，そこに人材があ り，マーケットとしての将来性があれば，プロ 興行が行われることを示している. 1990年代以 降，世界各地で小規模なプロ野球リーグが勃興 しているが，これらは，このような潮流を示す ものであると言える.

野球のグローバル化研究についての第一人者 と言ってょいKleinは, 人材獲得網の拡大とし ての野球の普及に関して, 裕福な欧州には可能 性を見出さず，貧困脱出のツールとしての途上 国における野球普及にその可能性を見出してい る ${ }^{4)}$ ししかし，イタリアにおけるプロリーグの 発足や, $\mathrm{WBC} へ の$ 参加国数の拡大と, それに 伴う欧州における予選大会の開催（2012）など を考えると, MLBの人材獲得網, マーケット の拡大としての野球の普及は, 彼の予想を超え た規模で現在進んでいると考えられる.

本書において紹介されている兼業選手の多 さ，サッカーをはじめとする英国スポーツのオ フシーズン・スポーツとしての競技，そして既 存の施設を利用した興行などの半世紀以上前の 英国プロ野球の諸相は, 現在の先進国における 小規模プロ野球リーグの運営におお扔いに示唆を 与えるのではないか. なぜならば, 現在の欧州 に拉けるサッカーの巨大スポーツビジネス化を 目の当たりにすると, この大陸において，野球 がメジャースポーツになることは考えにくく, 
今後の欧州における野球のプロ化, スポーツビ ジネス化の進展は, あくまで北米への人材供給 を主目的とした,「マイナーリーグ」としての それにとどまるものと考えられるからである. 実際,「文化へゲモニー」の時代に野球が伝来 しながら, 英国の文化的優勢のため, その普及 が進まず, 現在においても, 野球がマイナース ポーツにとどまっている豪州におけるプロリー グの展開は, かつての英国プロ野球に類似した ものとなっている ${ }^{5)}$.

現在のスポーツの普及・拡大は, 資本との結 びつきを強めたものに変容しているが, この 変容の中, 欧州においては, MLBの直接間接 の関わりの下, 各国で組織化が進み, 多くの 米国人選手がプロ選手としてプレーしている. Kleinが否定的にとらえた野球における欧州市 場は, 今後, 新たな選手プール, マーケティン グ先として大きな可能性を秘めているが, 自ら 米国のマイナーリーグから欧州球界へとプレー ヤーとして渡った著者による英国野球の源流を 探った本著は, 欧州に野球普及の基盤が存在す るという点を明らかにしたという点において貴 重であると言える.
本書評は財団法人松下幸之助記念財団2011年 度研究助成を受けた研究の一部として執筆した ものである。

\section{参 考 文 献}

1) グットマン・アレン, 谷川稔他訳 ; 『スポーツ と帝国〜近代スポーツと文化帝国主義』昭和堂, 1997.

2 ) マクガイヤー・ジョセフ, 東方美奈子・松村和 則訳 ; 「スポーツ化とグローバル化 : プロセス 社会学のパースペクティブ」、『ポーツ社会学 研究』7,pp.13-22, 1999.

3 ) 石原豊一;「グローバル化に扔けるスポーツ労 働移動の変容 -「ベースボール・レジーム」 の拡大と新たなアスリートの越境 -」, 立命館 大学大学院国際関係研究科2011年度博士学位 請求論文, 2011.

4 ) Klein, Alan; "Growing the Game: The Globalization of Major League Baseball”, Yale University Press, 2006.

5 ）石原豊一; 「ベースボールにみるグローバル化 (3) - 北米野球のリロケート先としてのオース トラリア」, 『立命館国際研究』25(1), ページ未定, 2012 . 